\title{
Katse vuoteen 2100
}

\author{
Aikuiskasvatuksen Tutkimusseuralla (ATS) \\ on takanaan 80 vuotta tieteenalan kehittämistä. \\ Miltä seura näyttää 80 vuoden kuluttua?
}

PÄIVI SIIVONEN

puheenjohtaja

ja esihenkilö, FT,

yliopistotutkija Itä-

Suomen yliopistossa ja

aikuiskasvatuksen dosentti

Helsingin yliopistossa

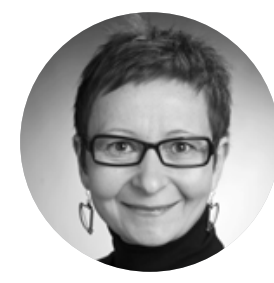

"ATS on sulautunut osaksi kansainvälistä globaalia virtuaalista tiedeseuraverkostoa. Se järjestää verkossa massakonferensseja, tuottaa mooceja ja pyörittää massiivisia tutkimushankkeita, joissa tuotetaan julkaisuja massiivisten huippukirjoittajatiimien toimesta huipputahtiin. Suomeksi ei enää julkaista tiedettä - se olisi silkkaa ajanhukkaa. Tehokkuus, huippuus ja nopeus ovat valttia."

\section{OUTI YLITAPIO-}

MÄNTYLÄ

johtokunnan jäsen, KT, dosentti ja yliopistonlehtori Oulun yliopistossa

"Elinvoimainen tutki-

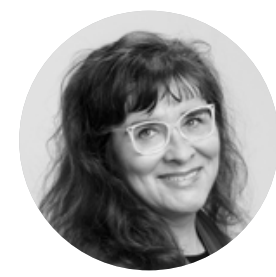
musseura tuo sivistyksellistä koulutuksen ja työelämän tutkimusta esiin. Seurassa käydään edelleen innoittavaa tieteellistä keskustelua.”
PÄIVI HÖKKÄ

johtokunnan jäsen,

$\mathrm{KT}$, dosentti ja tutkija

Jyväskylän yliopistossa

”Tässä maailma-

najassa mennään niin

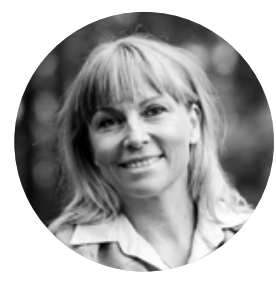

sumussa tulevaisuuden suhteen, että ensi

vuodenkin veikkaaminen on hankalaa. Mahtaakohan 80 vuoden päästä tekoäly hoitaa jo nämäkin hommat?"

\section{JOHANNA KALLIO} johtokunnan varajäsen, $\mathrm{KM}$, apurahatutkija Tampereen yliopistossa

"Optimistinen puoli minusta toivoo, että

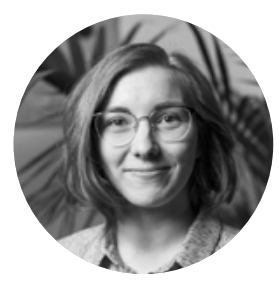
aikuiskasvatuksen potentiaali merkityksellisen elämän muotoutumisessa ja löytämisessä on muistettu uudelleen. Materian kulutuksen sijaan ihmiset voivat keskittyä toisiinsa ja itseensä ja tavoitella hyvää elämää uudenlaisessa, ekokriisin muuttamassa maailmassa. ATS jatkaa näin sitä työtä, jota varten se perustettiin: luomaan toivoa kriisien keskelle." 
ANU KAJAMAA

johtokunnan jäsen,

FT, dosentti ja

yliopistonlehtori

Helsingin yliopistossa

"ATS vastaa ajankoh-

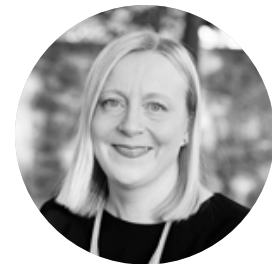

taisiin tutkimusteemoihin, keskusteluihin ja yhteiskunnallisiin tieteellisesti korkeatasoisella aikuiskasvatustieteellisellä tutkimuksella. Seuralla on kansallista ja kansainvälistä näkyvyyttä ja tiivistä yhteistyötä kotimaisten yliopistojen ja opiskelijoiden kesken."

MIRVA HEIKKILÄ tiedottaja, KM, OTM, yliopisto-opettaja ja väitöskirjatutkija Turun yliopistossa

"ATS tarjoaa edelleen

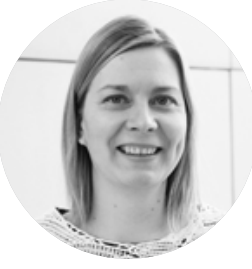
sekä kriittisiä että toivoa herättäviä näkökulmia ajankohtaisiin haasteisiin.”

\section{TIINA TUIJULA}

sihteeri, KT,

yliopistonlehtori Turun

yliopistossa

"ATS tekee aktiivisesti yhteistyötä muiden tie-

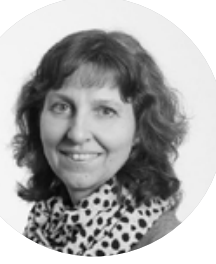
deseurojen kanssa kulttuurissa, jossa aikuisten hyvinvointiin ja hyvän elämän kokemukseen kiinnitetään yhä enemmän huomiota ja arvostusta."

\section{NINA HALTIA}

varaesihenkilö, $\mathrm{KT}$, tutkijatohtori Turun yliopistossa

"ATS on ennakkoluuloton, vilkkaasti keskusteleva ja yhteiskuntaan vaikuttava yhteisö."
ANNIKA PASTUHOV

johtokunnan varajäsen,

$\mathrm{KT}$, tutkijatohtori

Linköpingin yliopistossa

"Elinvoimainen yhdistys kokoaa tutkijoita

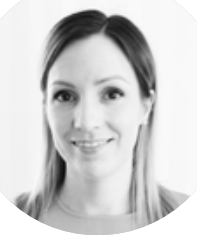
monelta tieteenalalta. Kiinnostus kasvun ja sivistyksen kysymyksiin vain lisääntyy yhä enemmän yhteen kietoutuneessa globaalissa maailmassa. Kiitos kehittyneen käännöstekniikan, ATS toimii sujuvasti sekä suomeksi että muilla kielillä. Voimme pitää yhteyksiä globaalisti."

\section{KATRIINA TAPANILA}

rahastonhoitaja, KM,

KTM, projektitutkija

Tampereen yliopistossa

"Väestön ikääntyminen ja moninaistuminen

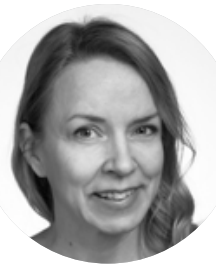
sekä työelämän teknologisoituminen tuovat uusia oppimishaasteita ja tarvetta inhimillisen näkökulman esiintuomiseen. ATS ja sen edistämä aikuiskasvatuksellinen tutkimus ovat tärkeitä, kun vastataan tulevaisuuden haasteisiin."

\section{HELI MUTANEN} johtokunnan jäsen, KM, yliopisto-opettaja ItäSuomen yliopistossa

"ATS on virtuaalisesti kuuluva ja näkyvä tie-

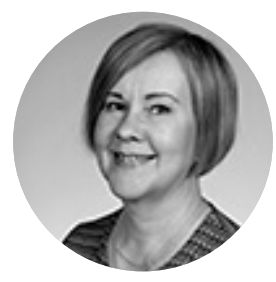
teellinen seura, joka tarttuu ahkerasti ajan aikuiskasvatuksellisiin teemoihin ja ennakoi tulevia teemoja. Seuralla on laaja aktiivinen tutkijajäsenistö ja opiskelijajäsenistö."

\section{Seuraa toimintaa:}

www.aikuiskasvatuksentutkimusseura.fi 